\title{
Determinants of Economic Development: A Case of Gulf Cooperation Council (GCC) Countries
}

\author{
Majed Alharthi ${ }^{1}$ \\ ${ }^{1}$ College of Business, Finance Department, King Abdulaziz University, Rabigh, Saudi Arabia \\ Correspondence: Majed Alharthi, College of Business, Finance Department, King Abdulaziz University, Rabigh, \\ P.O. Box. 344, Zip Code. 21911, Saudi Arabia. E-mail: mdalharthi@kau.edu.sa
}

Received: August 25, 2019

Accepted: September 19, 2019

Online Published: October 8, 2019

doi:10.5539/ijef.v11n11p12

URL: https://doi.org/10.5539/ijef.v11n11p12

\begin{abstract}
The main objective of this research is to identify the determinants of economic development in Gulf Cooperation Council (GCC) countries over the period of 1996-2016. The economic growth of GCC countries has slowed down due to a sharp drop in oil prices as GCC countries are depending on oil exportation for their economies. The GCC countries preferred to diversify their economies through the strategic plans called Vision 2030. The Vision 2030 for Gulf countries started in Saudi Arabia in 26 April 2016 when the Crown Prince (Mohammad bin Salman Al-Saud) declared that Saudi Arabia has to not depend on oil exportation substantially and that the diversification of oil is a must. The economic growth can be measured through the gross domestic production (GDP). Higher GDP indicates a better economy and higher standards of lives (welfare). Based on this, this research is finding the main indicators of economic development through regressions of fixed-effects model (FEM), random-effects model (REM), generalized methods of moments (GMM) and generalized least squares (GLS) models. The results show that production and rule of law strongly support the economy. In contrast, political instability and a larger population impact economic growth significantly and negatively. In addition, the global financial crisis (GFC) also decreased the economic strength significantly. This study helps the policymakers in economics sector to focus on the positive determinants and to avoid (or reduce) the implementation of the negative factors. In addition, the researcher on economics can be benefited from this study.
\end{abstract}

Keywords: gross domestic production, Gulf Cooperation Council, economic growth, Vision 2030

\section{Introduction}

Finding the determinants of economic growth is becoming very important due to increases in global financial threats. Many studies have focused on the relationship between economic growth and macroeconomic variables (e.g. Donou-Adonsou, 2019; Camarero et al., 2019). Knowing the positive determents of the economy would help policymakers to enhance the economy through applying positive strategies. On the other side, negative indicators should also serve as guides to avoid focusing on ineffective strategies.

This paper aims to find the correlation between gross domestic production (GDP) per capita and its determinants of GCC countries through the period of 1996 to 2016. Based on the International Monetary Fund (2019), the GCC countries depend on oil to support their economies. However, in 2015, the oil prices suffered from high supplies with lower demands which caused financial crises. In 2016, Saudi Arabia decides to diversify its economy through implementing a program called Vision 2030 that was first announced by the Kingdom of Saudi authority (KSA Vision, 2030). There are many methods in the GCC region for improving economies such as entertainment and industrial sectors.

This study aims to contribute towards this issue as few studies have focused on the GCC region to find economic growth determinants (e.g., Gazdar et al., 2018). In addition, the data of the study is up to date compared to the other studies. Moreover, this article examines whether or not the Arab Spring significantly influence the economies of GCC countries. The objective of this research is to clarify the questions below:

Q1: What are the main positive and significant indicators of economic development in GCC countries?

Q2: What are the main negative and significant indicators of economic development in GCC countries?

Section 2 includes the literature review, section 3 presents the methods and a description of the data, section 4 
discusses the main findings and section 5 concludes the study as whole.

\section{Literature Review and Conducting Hypotheses}

\subsection{Literature Review}

A limited number of studies have focused on finding the factors of economic growth in the GCC region. Most studies have concentrated on developing and developed economies. This section presents the recent studies that examine economic growth indicators.

Awdeh and Hamadi (2019) examined the factors that hindered economic development in 18 Middle Eastern and Northern African (MENA) countries over the period of 2002-2016. The main outcomes of this study concluded that the following factors hinder the GDP: military spending, public debts, population growth, increase of corruption, trade deficit, political instability and lower levels of technology adoption. In this study, the policymakers of MENA countries will benefit from identifying the negative factors that significantly affect their economic growth.

Donou-Adonsou (2019) tested the GDP per capita indicators of Sub-Saharan countries through the period of 1993-2015. The statistical model that he used to examine these correlations was the fixed-effects model. The main findings of this study suggest that more trade in the Sub-Saharan countries led to better economic growth. In addition, there is a significant and negative association between GDP per capita and GDP. Ogundari and Awokuse (2018) also focused on Sub-Saharan countries over the period of 1980-2008. This study also confirmed that trade and GDP per capita have a significant and positive relationship and that larger population sizes significantly decrease the economic development. Another study on African Sub-Sahara was conducted by Zahonogo (2016) during the period of 1980-2012. This paper proposed that trade supports the economy. In contrast, significant and negative indicators that influenced the economy included: GDP, and inflating population and economic crises (debts).

Another recent study of Iwanicz-Drozdowska et al. (2019) focused on the determinants of economic growth in 14 Central, Eastern and South-eastern Europe (CESEE) countries. This study covered the period of 1995-2015, and, statistically, the data has been analysed through the GMM model. The main results of this study suggest that higher stock market capitalization led to better economies through that period. Moreover, depending on credit reduction, the economic stability increased significantly. This result encouraged the CESEE countries to decrease loans.

Boukhatem and Moussa (2018) found the determinates of economies for MENA countries during the period of 2000-2014. The main findings of this study show that there is a significant and negative correlation between economic development and trade openness. This result encourages investors to reduce their investment. Best and Burke's (2018) findings confirmed the same conclusion while the results of Raheem et al. (2016) encourage investors to increase their spending on enterprises.

Gazdar et al. (2018) focused their study on GCC countries over the period of 1996-2016. The fixed-effects model was used to analyse their data. The GDP was found to enhance the GDP per capita in this study whereas trade and inflation had a significant and negative impact on economic development.

\subsection{Hypotheses Formulation}

From the recent studies, we can conclude the main hypotheses to be examined in this study as:

\section{1). GDP}

Most studies agreed that there is a significant and positive correlation between the GDP and GDP per capita (Donou-Adonsou, 2019; Gazdar et al., 2018; Smaouia \& Nechib, 2017). On the other side, some studies confirmed a negative relationship (Raheem et al., 2016; Flachaire et al., 2014). However, this study attempts to test the association between GDP and GDP per capita through the following hypothesis:

Hypothesis $\mathbf{1}\left(\mathbf{H}_{\mathbf{1}}\right)$ : GDP significantly affects economic growth in GCC countries

\section{2). Foreign direct investment (FDI)}

Few studies show the impact of FDI on economic growth. Iamsiraroj (2016) claims that FDI supported the economies of 124 countries during the period of 1971-2010. Therefore, the second hypothesis can be formulated as:

Hypotheses $2\left(\mathbf{H}_{\mathbf{2}}\right)$ : FDI significantly affects economic growth in GCC countries

3). Inflation

A comprehensive number of recent studies investigated the influence of inflation on economic growth. Most 
studies suggested that inflation slowed economies significantly (Kim et al., 2018; Smaouia \& Nechib, 2017). In this case, central banks can apply some strategies to reduce inflation and lending rates. The third hypnosis is:

Hypothesis $3\left(\mathbf{H}_{3}\right)$ : Inflation significantly affects economic growth in GCC countries

4). Unemployment

Logically, higher unemployment rates lead to lower development. This was determined by several studies such as Arshad et al. (2016) on Pakistan and Bere et al. (2014) on Romania. Based on this, this study tests the association between unemployment and GDP per capita through the hypothesis:

Hypothesis $4\left(\mathbf{H}_{4}\right)$ : Unemployment significantly affects economic growth in GCC countries

\section{5). Corruption}

Arshad et al. (2016) summarized that corruption was one of the main negative indicators that impact Pakistani's economy during the period of 1991-2011. The fifth hypothesis can be constructed as:

Hypothesis $5\left(\mathbf{H}_{5}\right)$ : Corruption significantly affects economic growth in GCC countries

6). Population

The majority of the previous researches agreed that larger populations significantly lower the economic growth (e.g. Camarero et al., 2019; Ogundari \& Awokuse, 2018; Zahonogo, 2016; Teixeiraa \& Queirós, 2016). In contrast, a few studies confirmed a positive and significant relationship between population and economic growth (Masoud \& Hardaker, 2012). In this study sixth hypothesis can be tested as:

Hypothesis $6\left(\mathbf{H}_{\mathbf{6}}\right)$ : Population significantly affects economic growth in GCC countries

\section{7). Political instability}

This variable shows the percentage of the political instability. A higher percentage means that the country suffers from political challenges, which leads to rebellions (protests) and can affect an economy badly. Focusing on the recent studies, Radu (2015) confirmed that the association between political stability and economic growth is significant and positive. However, Raheem et al. (2016) found an insignificant correlation between political stability and economic development. Therefore:

Hypothesis $\mathbf{7}\left(\mathbf{H}_{7}\right)$ : Political stability significantly affects economic growth in GCC countries

8). Rule of quality

This indicator gauges the effectiveness of the government to implement and maintain policies and regulations to enhance the private sector. Raheem et al. (2016) reported that a higher percentage of rule of quality supported the economy significantly. This means that there is a strong linkage between the public and private sectors. This study is testing the hypothesis of the rule of quality through:

Hypothesis $8\left(\mathbf{H}_{\mathbf{8}}\right)$ : Rule of quality significantly affects economic growth in GCC countries

9). Rule of law

This measurement refers to the strength of applying the system and the rules. In other words, a greater percentage represents more effectiveness for imposing the regulations by the government. The results of Iwanicz-Drozdowska (2019) show a significant and positive association between the GDP (production) and rules of law. However, some studies indicated insignificant correlations (Gazdar, 2018; Raheem et al., 2016). The hypothesis for rule of law is:

Hypothesis $9\left(\mathbf{H}_{9}\right)$ : Rule of law significantly affects economic growth in GCC countries

10). Trade

In most cases, higher competition (trade) allowed better economies (Zahonogo, 2016; Raheem et al., 2016; Iamsiraroj, 2016). On the other side, some studies go against this conclusion and argue that lower trade strengthens economies (Best \& Burke, 2018; Boukhatem \& Moussa, 2018). The tenth hypothesis is:

Hypothesis $10\left(\mathbf{H}_{10}\right)$ : Trade significantly affects economic growth in GCC countries

\section{1). Global financial crisis (GFC)}

Limited number of studies focused on the effects of the GFC on economic development. Example, Bere et al. (2014) concluded that the Romanian economy was affected inversely through the period of the GFC (2007-2009). However, this study examines the GFC on GCC economies by the following hypothesis:

Hypothesis $11\left(\mathbf{H}_{11}\right)$ : GFC significantly affects economic growth in GCC countries 


\section{2). Arab Spring}

Based on the researcher knowledge, there is no study on the literature review that has examined the impact of Arab Spring on GDP per capita. Therefore, this study will test the correlation by the following hypothesis:

Hypothesis $12\left(\mathbf{H}_{12}\right)$ : Arab Spring significantly affects economic growth in GCC countries

\section{Methodology}

\subsection{Descriptive Data}

The main sources of the data are International Monetary Fund (IMF), World Bank and United Nations Conference on Trade and Development (UNCTAD). There is six GCC countries in this study as Bahrain, Kuwait, Oman, Qatar, Saudi Arabia, and the United Arab Emirates (UAE). An extensive period is covered in this research between 1996 to 2016, this period has important challenges for the whole GCC countries. Examples, the GFC that happened through the period of 2007-2009 and Arab Spring (political revelations) that occurred in 2011. However, in the study, the dependent variable is GDP per capita and the independent variables are GDP, FDI, inflation, unemployment, corruption, population, trade size, political instability, rule of quality, rule of law, GFC and Arab Spring. Table 1 illustrates the descriptive statistics summary for the whole data of the study.

Table 1. Descriptive statistics summary of the data

\begin{tabular}{|c|c|c|c|c|c|c|c|}
\hline \multirow{2}{*}{ Variables } & \multirow{2}{*}{ Definition } & \multicolumn{5}{|c|}{ Statistics } & \multirow{2}{*}{$\begin{array}{l}\text { Expected } \\
\text { Sign }\end{array}$} \\
\hline & & Obs & Mean & S.D. & Min & Max & \\
\hline \multicolumn{8}{|l|}{ Dependent variable } \\
\hline GDP per capita & Log (GDP per capita) & 126 & 10.038 & 0.641 & 8.74 & 11.39 & ----- \\
\hline \multicolumn{8}{|c|}{ Independent variables } \\
\hline GDP & $\log (\mathrm{GDP})$ & 126 & 24.992 & 1.256 & 22.53 & 27.35 & + \\
\hline FDI & $\log (\mathrm{FDI})$ & 126 & 6.639 & 1.996 & 1.29 & 10.58 & + \\
\hline Inflation & Inflation rates & 126 & 0.0627 & 0.161 & -0.05 & 1.55 & - \\
\hline Unemployment & $\begin{array}{l}\%, \text { higher percentage indicates higher } \\
\text { unemployment }\end{array}$ & 126 & 0.057 & 0.059 & 0.001 & 0.198 & - \\
\hline Corruption & $\%$, higher percentage indicates higher corruption & 126 & 0.683 & 0.105 & 0.48 & 0.91 & - \\
\hline Population & $\%$, higher percentage indicates higher population & 126 & 14.954 & 1.155 & 13.17 & 17.29 & - \\
\hline Political instability & $\begin{array}{l}\% \text {, higher percentage indicates higher political } \\
\text { instability }\end{array}$ & 126 & 0.604 & 0.21 & 0.09 & 0.92 & - \\
\hline Rule of quality & $\%$, higher percentage indicates higher rule of quality & 126 & 0.646 & 0.097 & 0.4 & 0.83 & + \\
\hline Rule of law & $\%$, higher percentage indicates higher rule of law & 126 & 0.649 & 0.066 & 0.48 & 0.8 & + \\
\hline Trade & $\%$, higher percentage indicates higher trade & 126 & 0.929 & 0.51 & 0 & 2.05 & + \\
\hline $\begin{array}{l}\text { Global financial } \\
\text { crisis }\end{array}$ & $\begin{array}{l}\text { Dummy }=1 \text { for the period } 2007-2009 \text {, otherwise } \\
\text { zero }\end{array}$ & 126 & 0.142 & 0.351 & 0 & 1 & - \\
\hline Arab Spring & $\begin{array}{l}\text { Dummy = } 1 \text { for the period 2011-2016, otherwise } \\
\text { zero }\end{array}$ & 126 & 0.285 & 0.453 & 0 & 1 & - \\
\hline
\end{tabular}

Sources: UNCTAD (2019), World Bank (2019) and IMF (2019).

\subsection{Regression of GDP Per Capita}

The data will be analysed through using fixed-effects, random-effects, generalized methods of moments and generalized least squares regressions. The regression of GDP per capita is:

$$
\begin{gathered}
\text { LGDPP }_{t}=\alpha+\beta_{1} L_{\text {LDPP }}+\beta_{2} \text { LFDI }_{i t}+\beta_{3} \text { INFLATION }_{i t}+\beta_{4} \text { UNEMPLOYMENT }_{i t}+\beta_{5} \text { CORRUPTION }_{i t}+\beta_{6} \\
\text { LPOPULATION }_{i t}+\beta_{7} \\
\text { PINSTABILITY }_{i t}+\beta_{8} R Q U A L I T Y_{i t}+\beta_{9} R L A W+\beta_{10} L T R A D E+\beta_{11} G F C+\beta_{12} \\
\text { ASPRING }+\varepsilon
\end{gathered}
$$

Where:

$\alpha$ is the constant; $L G D P P_{t}$ donates the natural logarithm GDP per capita; $L G D P_{i t}$ is the natural logarithm of GDP; $L F D I_{i t}$ represents the natural logarithm of FDI; INFLATION ${ }_{i t}$ indicates the percentage of the inflation rate [consumer price index (CPI)]; UNEMPLOYMENT ${ }_{i t}$ shows the percentage of unemployment rate; CORRUPTION $_{i t}$ is the corruption percentage; LPOPULATION ${ }_{i t}$ denotes the natural logarithm of population; $L T R A D E_{i t}$ indicates the natural logarithm of trade size; $G F C_{t}$ is the dummy of global financial crisis period; $A S P R I N G_{t}$ represents the dummy of Arab Spring period; $\varepsilon$ is the error 
Avoiding the multicollinearity in the data is very important, for this, the test of the correlation is conducted in Table 2. The correlation values do not exceed $70 \%$, this means that the data can be analysed safely (with no errors).

Table 2. Correlation matrix for variables

\begin{tabular}{|c|c|c|c|c|c|c|c|c|c|c|c|c|c|}
\hline Correlation Matrix & 1 & 2 & 3 & 4 & 5 & 6 & 7 & 8 & 9 & 10 & 11 & 12 & 13 \\
\hline 1. GDP per capita & 1 & & & & & & & & & & & & \\
\hline 2. GDP & 0.40 & 1 & & & & & & & & & & & \\
\hline 3. FDI & 0.40 & 0.56 & 1 & & & & & & & & & & \\
\hline 4. Inflation & -0.28 & -0.19 & -0.19 & 1 & & & & & & & & & \\
\hline 5.Unemployment & -0.56 & -0.27 & -0.11 & 0.43 & 1 & & & & & & & & \\
\hline 6. Corruption & 0.37 & -0.11 & -0.04 & 0.14 & -0.02 & 1 & & & & & & & \\
\hline 7. Population & 0.31 & -0.08 & -0.14 & 0.19 & 0.18 & 0.61 & 1 & & & & & & \\
\hline 8. Political instability & 0.27 & -0.24 & 0.12 & -0.14 & -0.00 & 0.49 & 0.16 & 1 & & & & & \\
\hline 9. Rule of quality & 0.50 & -0.04 & -0.11 & 0.04 & -0.11 & 0.64 & 0.48 & 0.54 & 1 & & & & \\
\hline 10. Rule of law & -0.11 & 0.66 & 0.39 & -0.05 & 0.01 & -0.33 & -0.26 & -0.41 & -0.32 & 1 & & & \\
\hline 11. Trade & 0.32 & -0.38 & 0.01 & -0.01 & -0.08 & 0.50 & 0.14 & 0.68 & 0.43 & -0.59 & 1 & & \\
\hline 12. Global financial crisis & 0.19 & 0.13 & 0.27 & 0.00 & 0.00 & 0.05 & 0.02 & 0.03 & -0.00 & 0.04 & -0.00 & 1 & \\
\hline 13. Arab Spring & 0.36 & 0.40 & 0.28 & -0.14 & -0.09 & -0.07 & -0.22 & 0.12 & 0.19 & 0.23 & 0.207 & -0.2 & 1 \\
\hline
\end{tabular}

\section{Results and Discussion}

Table 3 illustrates the empirical statistical findings of the determinants of GDP per capita in GCC countries over the period of 1996-2016. There are significant correlations between GDP per capita and GDP, corruption, political stability, rule of quality, rule of law, population and global financial crisis. The section below explains the significant relationships for GCC counties.

a. GDP. As expected, results show that there is a significant and positive association between GDP and GDP per capita. This result is consistent with Donou-Adonsou (2019) Gazdar et al. (2018) and Smaouia and Nechib (2017). The findings of the regressions encourage GCC countries to produce more products and services to support their economies. On the contrary, Raheem et al. (2016) and Flachaire et al. (2014) approved the opposite conclusion.

b. Corruption. As predicted, the finding propose that higher corruption rates lead to lower economic development. Arshad et al. (2016) provided the same conclusion. This means that, in GCC countries, governments need to raise the control of corruption to enhance economic stability.

c. Political instability. It was highly expected that the political instability influences the GDP per capita significantly and inversely as in Table 3. The study of Radu (2015) on the Central and East European countries claimed that higher political stability rates allowed for an increased production of goods and services through the period of the study. Overall, sometimes political stability cannot be controlled by governments, especially when standards of living (welfare) continuously decline.

d. Rule of quality. Table 3 illustrates a significant and negative relationship between GDP per capita and rule of quality. Raheem et al. (2016) confirmed an opposite result as rule of law increased the GDP for 71 countries.

e. Rule of law. The results reveal that a stronger rule of law led to enhanced economies of GCC countries. This outcome is encouraging the governments to increase the supervisions and raise the awareness of law-abiding amongst residents. This finding is in line with the conclusion of Iwanicz-Drozdowska (2019). As mentioned in the literature review, Gazdar (2018) and Raheem et al. (2016) found an insignificant correlation between economic development and rule of law.

f. Population. As expected, the statistical outputs in Table 3 indicate that population growth in GCC countries affected the economies significantly and negatively. This result is in line with Ogundari and Awokuse (2018), Teixeiraa and Queirós (2016) and Flachaire et al. (2014). The findings in this study allow GCC policymakers to reduce their population numbers. This could be implemented through increasing tax rates. However, Masoud and Hardaker (2012) pointed that higher population numbers support the economies of emerging countries.

g. GFC. The GFC has impacted the economies of GCC significantly and inversely (see Table 3). This result is consistent with the study of Zahonogo (2016) on 42 sub-Saharan African countries. By contrast, the study of Bere et al. (2014) on Romania suggested that, during the period of the GFC, the economy was still growing. 
Table 3. Statistical results estimations for GCC countries

\begin{tabular}{|c|c|c|c|c|}
\hline Model & FEM & REM & GMM & GLS \\
\hline Dependent Variable & GDP per capita & GDP per capita & GDP per capita & GDP per capita \\
\hline \multicolumn{5}{|l|}{ Independent Variables } \\
\hline \multirow[t]{2}{*}{ GDP } & $1.001 * * *$ & $0.9995^{* * *}$ & $1.0010^{* * *}$ & $1.0011^{* * *}$ \\
\hline & $(0.0023)$ & $(0.0017)$ & $(0.0016)$ & $(0.0017)$ \\
\hline \multirow[t]{2}{*}{ FDI } & 0.0002 & 0.0004 & 0.0005 & 0.0005 \\
\hline & $(0.0004)$ & $(0.0003)$ & $(0.0004)$ & $(0.0003)$ \\
\hline \multirow[t]{2}{*}{ Inflation } & 0.0027 & 0.0021 & -0.0002 & -0.0002 \\
\hline & $(0.0034)$ & $(0.0031)$ & $(0.0014)$ & $(0.0031)$ \\
\hline \multirow[t]{2}{*}{ Unemployment } & 0.0197 & -0.0062 & 0.0137 & 0.0137 \\
\hline & $(0.0373)$ & $(0.0131)$ & $(0.0127)$ & $(0.0131)$ \\
\hline \multirow[t]{2}{*}{ Corruption } & -0.0105 & $-0.0119 *$ & -0.0064 & -0.0064 \\
\hline & $(0.0083)$ & $(0.0068)$ & $(0.0069)$ & $(0.0068)$ \\
\hline \multirow[t]{2}{*}{ Political stability } & $-0.0155^{* *}$ & $-0.0089^{* *}$ & $-0.0089^{* *}$ & $-0.0089^{* *}$ \\
\hline & $(0.0064)$ & $(0.0037)$ & $(0.0039)$ & $(0.0037)$ \\
\hline \multirow[t]{2}{*}{ Rule of quality } & -0.0165 & $-0.0185^{* *}$ & $-0.0185^{* * *}$ & $-0.0185^{* *}$ \\
\hline & $(0.0105)$ & $(0.0073)$ & $(0.0062)$ & $(0.0073)$ \\
\hline \multirow[t]{2}{*}{ Rule of law } & $0.0263 * *$ & $0.0195^{*}$ & $0.0195 * *$ & $0.0195^{*}$ \\
\hline & $(0.0041)$ & $(0.0111)$ & $(0.0091)$ & $(0.0111)$ \\
\hline \multirow[t]{2}{*}{ Population } & $-1.0026 * * *$ & $-0.9996^{* * *}$ & $-1.0012 * * *$ & $-1.0012 * * *$ \\
\hline & $(0.0041)$ & $(0.0016)$ & $(0.0015)$ & $(0.0016)$ \\
\hline \multirow[t]{2}{*}{ Trade } & 0.0049 & 0.0008 & 0.0021 & 0.0021 \\
\hline & $(0.0035)$ & $(0.0015)$ & $(0.0016)$ & $(0.0015)$ \\
\hline \multirow[t]{2}{*}{ GFC } & $-0.0026^{*}$ & $-0.0021^{* *}$ & $-0.0033^{* *}$ & $-0.0033^{* *}$ \\
\hline & $(0.0016)$ & $(0.0015)$ & $(0.0015)$ & $(0.0015)$ \\
\hline \multirow[t]{2}{*}{ Arab Spring } & -0.0008 & -0.0001 & -0.0023 & -0.0023 \\
\hline & $(0.0021)$ & $(0.0016)$ & $(0.0016)$ & $(0.0016)$ \\
\hline \multirow[t]{2}{*}{ Constant } & 0.0069 & 0.0112 & -0.0044 & -0.0044 \\
\hline & $(0.03423)$ & $(0.0197)$ & $(0.0173)$ & $(0.0197)$ \\
\hline $\mathrm{N}$ & 126 & 126 & 126 & 126 \\
\hline $\mathrm{R}^{2}$ & 0.91 & 0.90 & 0.88 & 0.86 \\
\hline
\end{tabular}

Note. standard error in parentheses, ${ }^{* * *} \mathrm{p}<0.01,{ }^{* *} \mathrm{p}<0.05,{ }^{*} \mathrm{p}<0.10$.

\section{Conclusion}

This research aimed to find the positive and negative determinants of economic development for six GCC countries through the period 1996-2016. The sources of the data are the IMF, World Bank and UNCTAD. The statistical regressions for analysing the data were FEM, REM, GMM and GLS. The findings confirmed that production (of goods and services) and rule of law supported the economy significantly and positively. On the other side, political instability and population growth influenced economic development in a negative way. Moreover, the GFC reduced the economic growth significantly. This research should help regulators to analyse the weaknesses and strengths of their economies. Furthermore, academic researchers within economic disciplines can benefit from this study. There is a limitation of this study as some data was not found for the year 2017. In the future, more research can be conducted covering more countries, periods (like 2017 and 2018) and independent variables.

\section{References}

Arshad, A., Zakaria, M., \& Junyang, X. (2016). 'Energy prices and economic growth in Pakistan: A macro-econometric analysis,' Renewable and Sustainable Energy Reviews, 55, 25-33. https://doi.org/10.1016/j.rser.2015.10.051

Awdeh, A., \& Hamadi, H. (2019). Factors hindering economic development: Evidence from the MENA countries. International Journal of Emerging Markets, 14(2), 281-299. https://doi.org/10.1108/IJoEM-12-2017-0555

Bere, R. C., Otoiu, A., \& Bucerzan, I. (2014). Determinants of economic growth in cities acting as growth poles in regions from Romania. Procedia Economics and Finance, 10, 357-365.

Best, R., \& Burke, P. J. (2018). Electricity availability: A precondition for faster economic growth? Centre for Applied Macroeconomic Analysis, Working Paper, 1-26. https://doi.org/10.1016/j.eneco.2018.06.018

Boukhatem, J., \& Moussa, F. B. (2018). The effect of Islamic banks on GDP growth: Some evidence from 
selected MENA countries. Borsa Istanbul Review, 18(3), 231-247. https://doi.org/10.1016/j.bir.2017.11.004

Camarero, M., Peiró-Palomino, J., \& Tamarit, C. (2019). Growth in a time of external imbalances. Economic Modelling. https://doi.org/10.1016/j.econmod.2018.12.011

Chen, S. C., Chen, H. Y., Chang, C. C., \& Yang, S. L. (2016). The relation between sovereign credit rating revisions and economic growth. Journal of Banking \& Finance, 64, 90-100. https://doi.org/10.1016/j.jbankfin.2015.10.012

Donou-Adonsou, F. (2019). Technology, education, and economic growth in Sub-Saharan Africa. Telecommunications Policy. https://doi.org/10.1016/j.telpol.2018.08.005

Ductor, L., \& Grechyna, D. (2015). Financial development, real sector, and economic growth. International Review of Economics and Finance, 37, 393-405. https://doi.org/10.1016/j.iref.2015.01.001

Flachaire, E., Garcia-Penalosa, C., \& Konte., M. (2014). Political versus economic institutions in the growth process. Journal of Comparative Economics, 42(1), 212-229. https://doi.org/10.1016/j.jce.2013.05.001

Gazdar, K., Hassan, M. K., Safa, M. F., \& Grassa, R. (2018). Oil price volatility, Islamic financial development and economic growth in Gulf Cooperation Council (GCC) countries. Borsa Istanbul Review, 1-10. https://doi.org/10.1016/j.bir.2018.07.005

Iamsiraroj, S. (2016). The foreign direct investment-economic growth nexus. International Review of Economics and Finance, 42, 116-133. http://dx.doi.org/10.1016/j.iref.2015.10.044

International Monetary Fund. (2019). Retrieved from http://www.imf.org

Iwanicz-Drozdowska, M., Bongini, P., Smaga, P., \& Witkowski, B. (2019). The role of banks in CESEE countries: Exploring non-standard determinants of economic growth. Post-Communist Economies, 31(3), 349-382. https://doi.org/10.1080/14631377.2018.1505694

Kim, D. W., Yu, J. S., \& Hassan, M. K. (2018). Financial inclusion and economic growth in OIC countries. Research in International Business and Finance, 43, 1-14. http://dx.doi.org/10.1016/j.ribaf.2017.07.178

KSA Vision 2030. (2019). Retrieved from https://vision2030.gov.sa/en

Masoud, N., \& Hardaker, G. (2012). The impact of financial development on economic growth: Empirical analysis of emerging market countries. Studies in Economics and Finance, 29(3), 148-173. https://doi.org/10.1108/10867371211246830

Ogundari, K., \& Awokuse, T. (2018). Human capital contribution to economic growth in Sub-Saharan Africa: Does health status matter more than education? Economic Analysis and Policy, 58, 131-140. https://doi.org/10.1016/j.eap.2018.02.001

Radu, M. (2015). The Impact of Political Determinants on Economic Growth in CEE Countries. Procedia Social and Behavioral Sciences, 197, 1990-1996. https://doi.org/10.1016/j.sbspro.2015.07.579

Raheem, I. D., Ajide, K. B., \& Adeniyi, O. (2016). The role of institutions in output growth volatility-financial development nexus: A worldwide study. Journal of Economic Studies, 43(6), 910-927. https://doi.org/10.1108/JES-04-2015-0063

Smaoui, H., \& Nechi, S. (2017). Does sukuk market development spur economic growth? Research in International Business and Finance, 41, 136-147. http://dx.doi.org/10.1016/j.ribaf.2017.04.018

Teixeira, A. A. C., Anabela, S. S., \& Queirós, A. S. S. (2016). Economic growth, human capital and structural change: A dynamic panel data analysis. Research Policy, 45, 1636-1648. http://dx.doi.org/10.1016/j.respol.2016.04.006

United Nations Conference on Trade and Development. (2019). Retrieved from http://unctad.org

World Bank. (2019). Retrieved from https://www.worldbank.org

Zahonogo, P. (2016). Trade and economic growth in developing countries: Evidence from sub-Saharan Africa. Journal of African Trade, 3, 41-56. http://dx.doi.org/10.1016/j.joat.2017.02.001

\section{Copyrights}

Copyright for this article is retained by the author(s), with first publication rights granted to the journal.

This is an open-access article distributed under the terms and conditions of the Creative Commons Attribution license (http://creativecommons.org/licenses/by/4.0/). 